\title{
Fiscal Policy and the Nigerian Economy: An Econometric Review
}

\author{
Anyalechi Kenneth Chikezie ${ }^{1}$, Onwumere Josaphat Uchechukwu Joe ${ }^{1} \&$ Boloupremo Tarila $^{2}$ \\ ${ }^{1}$ Department of Banking and Finance. Faculty of Business Administration, University of Nigeria, Enugu \\ Campus, Nigeria \\ ${ }^{2}$ School of Foundation studies, University of Africa, Nigeria \\ Corresponding author: Anyalechi Kenneth Chikezie, Department of Banking and Finance. Faculty of Business \\ Administration, University of Nigeria, Enugu Campus, Nigeria. E-mail: anyalechikaycee@yahoo.com
}

Received: December 13, 2016

Accepted: February 9, 2017

Online Published: March 26, 2017

doi:10.5539/ijbm.v12n4p186

URL: https://doi.org/10.5539/ijbm.v12n4p186

\begin{abstract}
The paper examines fiscal policy regulations as a tool for enhancing economic growth and poverty reduction in Nigeria using data covering the period 1981-2014 obtained from Central bank of Nigeria and World Development Indicators. The study employed econometric methods of Ordinary Least Square (OLS), Augmented Dickey-Fuller (ADF) Unit Root test, Johansen Co-integration test and Vector auto-regression (VAR) to analyze data empirically. Results from data analyzed suggest that tax revenue, external borrowings, government domestic debt and government capital expenditure have not contributed significantly to economic growth and poverty reduction in Nigeria. However, government recurrent expenditure was found to be statistically significant and impacted on the gross domestic product per capita during the study period. This may be attributed to the reason that recurrent expenditure has a deep rooted and faster influence on growth than capital expenditure. Capital expenditure, which is a long-term expenditure, is more prone to misappropriation and theft, and also could be less growth enhancing. The empirical result is consistent with and strongly upheld the Keynesian's view that government expenditure causes economic growth.
\end{abstract}

Keywords: per Capita GDP, recurrent expenditure, capital expenditure, tax

\section{Introduction}

The intent of fiscal policy is essentially to stimulate economic and social development by pursuing a policy stance that ensures a sense of balance between taxation, expenditure and borrowing that is consistent with sustainable growth. However, the extent to which fiscal policy engenders economic growth continues to attract theoretical and empirical debate in developing and advanced countries. During the global recession and financial crisis of 2008 and onward, most advanced countries implemented a variety of active fiscal policies as large stimulus packages to mitigate this recession. In particular, since monetary policy options are restricted by the very low interest rates, which were central features of this recession, most governments relied much more on fiscal policy. For example, the U.S. enacted unprecedented fiscal expansion including the American Recovery and Reinvestment Act (ARRA) of 2009 which was a combination of tax cuts, transfers to individuals and states, and government purchases equal to 5.5\% of GDP Auerbach (2012). In 2008, the EU adopted the European Economic Recovery Plan (EERP) equivalent to $1.5 \%$ of the EU GDP Beetsma and Giuliodori (2011).

These examples are just a subset of the stimulus packages by G20 governments. According to Gemmell (2011), much larger G20 stimulus packages worth \$15 trillion over 2009-2010 were announced in 2009, expecting to stimulate GDP by $4 \%$ compared to the 'no stimulus' alternative. However, these large-scale fiscal stimulus packages have triggered a lively debate about the effectiveness of fiscal policy regulations. Until the early 1980s, fiscal policy was widely regarded as a useful tool for economic stabilization. However, its failure to boost economic growth in the wake of the oil shocks of the 1970s, and the associated increase in budget deficit and public debts, have led a lot of economists to be skeptical about the effectiveness of fiscal policy to smoothen cyclical fluctuations (Beetsma and Giuliodori, 2011), and fiscal policy has received less attention (Afonso and Sousa, 2012).

While policymakers continued to rely heavily on active fiscal policy as a policy instrument, as demonstrated during the current global recession, academic researchers have not reached a consensus about the effects of fiscal policy on macroeconomic variables, or about the magnitude of such effects. This stands in stark contrast to 
monetary policy, where a substantial consensus has been established between academics and policymakers as regards current inflation-targeting strategies and its effects on the economy Perotti, (2007); Beetsma, (2008); Fontana, (2009); and Auerbach, (2012). According to Arestis (2009), the new consensus on monetary policy has an implication that monetary policy is effective as a means of inflation control through changes in the interest rate via the Taylor Rule.

Moreover, this new consensus model is based on the new Keynesian theory of nominal rigidities and long-run vertical Phillips curve as well as the neoclassical theory of rational expectation and explicit optimization behaviour. However, there is less agreement regarding fiscal policy in both the theoretical model and empirical approach. The paper intends to examine the effect of fiscal policy as a regulatory tool on the growth of Nigeria's economy. The study is organized as follows: section two reviews theoretical and empirical literatures on fiscal policy, section three deals with the methodology, section four presents the data analysis and discussion while the last section 5 concludes the study.

\subsection{Theoretical and Empirical Framework}

Theoretical models on the effects of fiscal policy can be often distinguished by two main views developed with micro foundations: neoclassical theory and new Keynesian theory. For a fiscal expansion such as an increase in government spending or tax cut, both views predict rising output in the short term, but envisage different transmission mechanism. These different channels are attributed to different assumptions adopted by each theory and to the corresponding responses of private consumption and the labor market. Therefore, the key point of debate between the two theoretical views is about the effects of fiscal policy on private consumption and real wage in that predictions about the responses of these two variables to fiscal policy are consistent according to theoretical models in spite of various underlying assumptions.

For example, the neoclassical model predicts that an expansionary fiscal policy decreases private consumption and increases labor supply due to negative wealth effects and consequently an increase of labour supply causes a decline in the real wage. On the other hand, the new Keynesian model predicts that after positive fiscal shocks, real wage increases because of an increase in labour demand due to nominal price rigidities and imperfect competition, and the rising real wage also raises private consumption because of 'rule-of-thumb' by consumers Galí et al. (2007) or 'deep habits' Ravn et al. (2006). There is a similar disagreement about the effects of fiscal adjustments such as spending cuts or tax hikes: even the response of GDP is predicted differently to some degree. For instance, the neoclassical model can predict that fiscal adjustment implemented during the periods of fiscal stress has expansionary effects on output because of wealth effects or credibility effects, which is often called 'Non-Keynesian effects', in conflict with the traditional Keynesian perspective Bertola and Drazen, (1993); Sutherland, (1997).

In consequence, the need for empirical evidence to elucidate the issues in the theories examined has become expedient. Olawunmi and Ayinka (2007) examined the contribution of fiscal policy in the achievement of sustainable economic growth in Nigeria using slow growth model estimated with the use of ordinary least square method. It was found that fiscal policy has not been effective in the area of promoting sustainable economic growth in Nigeria. They however, stated that factors such as wasteful spending, poor policy implementation and lack of feedback mechanism for implemented policy evident in Nigeria, which is indeed capable of hampering the effectiveness, of fiscal policy, have made it impossible to come up with such a conclusion.

Adefeso and Mobalaji (2010) wrote on the fiscal-monetary policy and economic growth in Nigeria. Their major objective was to re-estimate and re-examine the relative effectiveness of fiscal and monetary policies on economic growth in Nigeria using annual data from 1970-2007. The Error correction mechanism and co-integration technique were employed to analyze the data and draw policy inferences. Their result showed that the effect of monetary policy is much stronger than fiscal policy. They suggested that there should be more emphasis and reliance on monetary policy for the purpose of economic stabilization in Nigeria.

Mueller (2011) investigated economic, political and institutional constraints to fiscal policy implementation in sub-Saharan Africa. It was found that planned fiscal adjustments or expansions are less likely to be implemented. The larger they are, the more inaccurate the growth forecasts they are based on. The finding supports on going efforts in the region to improve the quality and timeliness of economic data, enhance forecasting capacity, adopt realistic fiscal plans, and strengthen governance, budgetary institutions, and public financial management procedures. Ogbole, Amadi and Essi (2011) wrote on fiscal policy: its impact on economic growth in Nigeria (1970-2006). The study involves comparative analysis of the impact of fiscal policy on economic growth in Nigeria during regulation and deregulation periods. Econometric analysis of time series data from Central Bank of Nigeria was conducted. Results showed that there is difference in the effectiveness of fiscal policy in 
stimulating economic growth during and after regulation period. Appropriate policy mix, prudent public spending, setting of achievable fiscal policy targets and diversification of the nation's economic base, among others, were recommended.

In the same vein but covering a shorter period Adeoye (2006) analyzed the impact of fiscal policy on economic growth in Nigeria in 1970-2002. The finding shows that public investment negatively affects output growth implying that public expenditure has a crowding out effect on private investment.

Chuku (2010) uses quarterly data to explore the monetary and fiscal policy interactions in Nigeria between 1970-2008. The paper examines the nature of fiscal policies in Nigeria using vector auto-regression (VAR) model. The evidence indicates that monetary and fiscal policies in Nigeria have interacted in a counteractive manner for most of the sample period (1980-1994) while at other periods no symmetric pattern of interaction between the two policy variables was observed.

Huang and Padilla (2002) wrote on fiscal policy and implementation of the Walsh Contract for Central Bankers. They developed a simple macroeconomic model where the time inconsistency of optimal monetary policy is due to tax distortions. They concluded that implementing the optimal policy mix requires either that central bank enjoy primacy over the fiscal authority or that fiscal policy be also delegated to an independent authority. Omitogun and Ayinla (2007) examined empirically the contribution of fiscal policy in the achievement of sustainable economic growth in Nigeria. They used Solow growth model estimated with the use of ordinary least square method and found out that fiscal policy has not been effective in the area of promoting sustainable economic growth in Nigeria. They suggested that Nigerian government should put a stop to the incessant unproductive foreign borrowing, wasteful spending and uncontrolled money supply and embark on specific policies aimed at achieving increased and sustainable productivity in all sectors of the economy.

Amin (1999) analyzed the relationship between public and private investment stressing the crowding in or crowding out of private investment by public expenditures in Cameroon. Based on secondary data from the public sector, the results of a growth model show that the relevant factors have positive effects on growth while those of the investment model show the crowding in of infrastructures and social sector. The study concluded by recommending the relocation of more resources to productive sectors and increasing and sustaining of spending on those productive sectors or those components of public expenditures that crowd in the private sector.

Njoku and Ihugba (2011) looked at the relationship between unemployment and growth in Nigeria (1985-2009). One major findings of the study is that the economy grew by 55.5 percent between 1991-2006 and the population increased by 36.4 percent. This should ordinarily have resulted to a decrease in the rate of unemployment but rather unemployment increased by 74.8 percent. Davis, Ossowski and Fedelino (2003) looked at fiscal policy formulation and implementation in oil producing countries. Their study showed that resource dependent economies tend to grow more slowly than non-resource dependent ones at comparable levels of development. Poverty is still widespread in a number of oil-producing countries. They concluded that a pattern of fluctuating fiscal expenditures associated with oil volatility has entailed significant economic and social costs for a number of oil producers. Auerbach, (2009) suggested that for fiscal discretionary policy to be practiced on a large-scale attention must be paid to policy design.

\section{Research Methodology}

The study used data covering 1981-2014 mainly from secondary sources as fiscal policy and economic growth variables; the sources include Central Bank of Nigeria statistical bulletin and World Bank development economic indicators. The choice of secondary data is based on their authenticity and reliability. The operational methodology adopted is the multiple regression analysis ordinary least square (OLS) econometric technique, multiple regressions of the dependent variable (annual growth rate of gross domestic product per capita) and the independent variables (tax revenue, recurrent and capital expenditure, internal and external borrowing) in the specification of the model with a view to determining the nature and extent of the relationship that exists among the variables.

Statistical significance of the a priori theoretical relationship was tested and statistical significance or insignificance of the coefficients of the independent variables was established. Analysis of the mathematical sign of the coefficients was undertaken. A positive and statistically significant coefficient for the various dependent variables was interpreted as supporting the given hypothesis. The following linear models guided the analysis:

$$
\operatorname{logRPCIg}=b_{0} \pm b_{1} \log \mathrm{TR} \pm \mathrm{b}_{2} \log \mathrm{GED} \pm \mathrm{b}_{3} \log \mathrm{GDD} \pm \mathrm{b}_{4} \log \mathrm{GRE} \pm \mathrm{b}_{5} \log \mathrm{GCE} \pm \boldsymbol{v}
$$

Where:

LogRPCIg = Annual growth rate of gross domestic product Real Per capita 
$\operatorname{LogTR}=$ Tax Revenue

LogGED $=$ Government External Debt

$\operatorname{LogGDD}=$ Government Domestic Debt

$\operatorname{LogGRE}=$ Government Recurrent Expenditure

$\operatorname{LogGCE}=$ Government Capital Expenditure

$\beta_{0}=$ Intercept of the regression, $b_{1},,, b_{5}=$ coefficient of the regression

$u=$ Stochastic or error term.

The Vector Auto-regression (VAR) estimated from the model above is stated as follows:

$$
\begin{aligned}
& \operatorname{logRPCIg} \mathrm{t}_{\mathrm{t}}: \mathrm{x}_{1, \mathrm{t}}=\mathrm{c}_{1}+\phi_{11,1} \mathrm{x}_{1, \mathrm{t}-1}+\phi_{12,1} \mathrm{x}_{2 \mathrm{t}-1}+\phi_{13,1} \mathrm{x}_{3 \mathrm{t}-1}+\phi_{14,1} \mathrm{x}_{4 \mathrm{t}-1}+\phi_{15,1} \mathrm{x}_{5 \mathrm{t}-1},+\varepsilon_{1 \mathrm{t}} \\
& \operatorname{LogTR}_{\mathrm{t}}: \mathrm{x}_{2, \mathrm{t}}=\mathrm{c}_{2}+\phi_{16,1} \mathrm{x}_{1, \mathrm{t}-1}+\phi_{17,1} \mathrm{x}_{2 \mathrm{t}-1}+\phi_{18}, 1 \mathrm{x}_{3 \mathrm{t}-1},+\phi_{19,1} \mathrm{x}_{4 \mathrm{t}-1}+\phi_{20,1} \mathrm{x}_{5 \mathrm{t}-1}+\varepsilon_{2 \mathrm{t}} \\
& \operatorname{LogGED}:_{\mathrm{t}}: \mathrm{x}_{3, \mathrm{t}}=c_{3}+\phi_{21,1} \mathrm{x}_{1, \mathrm{t}-1}+\phi_{22,1} \mathrm{x}_{2 \mathrm{t}-1}+\phi_{23}, 1 \mathrm{x}_{3 \mathrm{t}-1}, \quad++\phi_{24,1} \mathrm{x}_{4 \mathrm{t}-1}+\phi_{25,1} \mathrm{x}_{5 \mathrm{t}-1}+\varepsilon_{3 \mathrm{t}} \\
& \operatorname{LogGDD} \mathrm{t}_{\mathrm{t}}: \mathrm{x}_{4, \mathrm{t}}=\mathrm{c}_{4}+\phi_{26,1} \mathrm{x}_{1, \mathrm{t}-1}+\phi_{27,1} \mathrm{x}_{2 \mathrm{t}-1}+\phi_{28}, 1 \mathrm{x}_{3 \mathrm{t}-1}, \quad+\phi_{29,1} \mathrm{x}_{4 \mathrm{t}-1}+\phi_{30,1} \mathrm{x}_{5 \mathrm{t}-1}+\varepsilon_{4 \mathrm{t}} \\
& \operatorname{LogGRE}_{\mathrm{t}}: \mathrm{x}_{5 \mathrm{t}}=\mathrm{c}_{5}+\phi_{3,1} \mathrm{x}_{1, \mathrm{t}-1}+\phi_{32,1} \mathrm{x}_{2 \mathrm{t}-1}+\phi_{33}, 1 \mathrm{x}_{3 \mathrm{t}-1}, \quad+\phi_{34,1} \mathrm{x}_{4 \mathrm{t}-1}+\phi_{35,1} \mathrm{x}_{5 \mathrm{t}-1}+\varepsilon_{5 \mathrm{t}} \\
& \operatorname{LogGCE}:_{\mathrm{t}}: \mathrm{x}_{5 \mathrm{t}}=\mathrm{c}_{6}+\phi_{36,1} \mathrm{x}_{1, \mathrm{t}-1}+\phi_{37,1} \mathrm{x}_{2 \mathrm{t}-1}+\phi_{38}, 1 \mathrm{x}_{3 \mathrm{t}-1}, \quad+\phi_{39,1} \mathrm{x}_{4 \mathrm{t}-1}+\phi_{40,1} \mathrm{x}_{5 \mathrm{t}-1}+\varepsilon_{6 \mathrm{t}}
\end{aligned}
$$

Where:

$\mathrm{t}-1$ is the variable lagged by a period

$\phi_{\mathrm{p}}(i=0,1,2,3 \ldots \mathrm{p})$ denotes the $(\mathrm{k} \times \mathrm{k})$-parameter matrices with $\phi_{\mathrm{p}}=0$

$\mathrm{c}$ are constants which maybe zeros

$\varepsilon_{\mathrm{t}}$ is a white noise

Hypothesis for the co-integration test is outlined below;

Null hypothesis $(\mathrm{H} 0): \mathrm{BI}=\mathrm{B} 2=\mathrm{B} 3=\mathrm{B} 4=0$ (No Co-integration)

Alternative hypothesis ( $\mathrm{H} 1)$ : $\mathrm{BI} \neq \mathrm{B} 2 \neq \mathrm{B} 3 \neq \mathrm{B} 4 \neq 0$ (Co-integration exists)

Logarithmic and seasonal adjustment levels of time series to determine the effect of the independent variable on the dependent variable were employed on data obtained.

The data for this study representing the independent variables tax revenue (TR), government external debt (GED), government domestic debt (GDD), government recurrent expenditure (GRE), government capital expenditure (GCE), were pooled together with the dependent variable Annual growth rate of gross domestic product Real Per capita (RPCIg) for the period 1981 to 2014. Multiple regression analysis is used to investigate the predictable power of the independent variables on the dependent variable. The analysis was however guided by the specified models as above.

\section{Results and Discussion}

The tables below shows the results of the ordinary least square test conducted on the specified model. The OLS results reveal the relationship that exists between the dependent variable and each of the independent variable

Table 1. Correlation Coefficient Matrices

\begin{tabular}{lc|c|c|c|c|c}
\hline & RPClg & LnGDD & LnGED & LnGCE & LnTX & LnGRE \\
\hline RPClg & 1. & & & & & \\
LnGDD & 0.48 & 1. & & & & \\
LnGED & 0.56 & 0.81 & 1. & & & \\
LnGCE & 0.45 & 0.98 & 0.8 & 1. & 1. & 1. \\
LnTX & 0.48 & 0.98 & 0.79 & 0.98 & 0.99 & 0.97 \\
LnGRE & 0.51 & 0.99 & 0.81 & 09 & \\
\hline
\end{tabular}

Notes: RPCIg= Annual growth rate of gross domestic product Real Per capita. LogGDD = Government Domestic Debt. LogGED $=$ Government External Debt. LogGCE $=$ Government Capital Expenditure. LogTX $=$ Tax Revenue. LogGRE $=$ Government Recurrent Expenditure.

Table 2. Descriptive Statistics of the variables 


\begin{tabular}{|c|c|c|c|c|c|c|}
\hline Statistic & RPClg & LnGDD & LnGED & LnGCE & LnTX & LnGRE \\
\hline Mean & 1.05 & 6. & 5.97 & 4.72 & 4.76 & 5.2 \\
\hline Variance & 57.53 & 3.99 & 3.74 & 4.07 & 5.66 & 5.14 \\
\hline Standard Deviation & 7.58 & 2. & 1.93 & 2.02 & 2.38 & 2.27 \\
\hline Minimum & -15.5 & 2.42 & 0.85 & 1.41 & 1.09 & 1.56 \\
\hline Maximum & 30.3 & 8.98 & 8.5 & 7.89 & 8.09 & 8.21 \\
\hline Median & 1.65 & 6.28 & 6.41 & 5.49 & 5.03 & 5.13 \\
\hline Skewness & 1.14 & -0.27 & -0.99 & -0.36 & -0.19 & -0.25 \\
\hline Kurtosis & 8.35 & 1.84 & 3.3 & 1.67 & 1.6 & 1.68 \\
\hline No of observation & 34 & 34 & 34 & 34 & 34 & 34 \\
\hline
\end{tabular}

Notes: RPCIg= Annual growth rate of gross domestic product Real Per capita. LogGDD = Government Domestic Debt. LogGED = Government External Debt. LogGCE $=$ Government Capital Expenditure. LogTX = Tax Revenue. $\log G R E=$ Government Recurrent Expenditure.

Table 3. Summary of ordinary least square results

\begin{tabular}{|c|r|r|r|}
\hline Variables & Coefficient & Standard Error & \multicolumn{1}{c|}{ p-level } \\
\hline Intercept & 12.25 & 0.1 & 0.15 \\
GDD & 0.09 & 0.06 & $0.05 E-10$ \\
GED & -0.14 & 0.02 & 0.06 \\
GCE & -0.09 & 0.05 & 0.31 \\
TAX & 0.06 & 0.06 & 0.08 \\
GRE & 0.11 & 0.06 & \\
\hline$T(5 \%)$ & 2.05 & & \\
\hline
\end{tabular}

$R^{2}=0.88$ Adjusted $R^{2}=0.86$ F-Stat $=41.53$

Source: Author's computation, 2016

From table, the relationship between the dependent variable (RPCIg) and the independent variables (DD, ED, CE, TAX and RE) can be deduced and expressed mathematically as:

$$
\mathrm{RPCIg}=12.25+0.09_{\mathrm{GDD}}-0.14_{\mathrm{GED}}-0.09_{\mathrm{GCE}}+0.06_{\mathrm{TAX}}+0.11_{\mathrm{GRE}}
$$

From the above result, the constant parameter is positive, showing that if all Independent variables are held constant, the dependent variable (GDP) will increase by 12.25 units. The coefficient of GDD is positively related to GDP with an estimate of 0.09 , which means that a $100 \%$ increase in domestic debt, will lead to an increase in GDP by 9 units. The coefficient GED is also negatively related to the GDP with a value of -0.14 , which means that an increase in external debt of the nation, will lead to a decrease in the GDP by 0.14 units. The coefficient of GCE is negatively related to GDP with an estimate of -0.09 , this implies that increase in capital expenditure will lead to a decrease in the GDP by 0.09 units. The coefficient TAX is also positive with a value of 0.06 , this means that if tax revenue is increased, GDP will increase by 0.06 units. GRE coefficient also showed a positive sign of 0.11 in value. This is an indicator that an increase in recurrent expenditure will lead to $\mathrm{n}$ increase in the value of GDP by 0.11 units

The coefficient of government capital expenditure, which shows negative, is not in any way surprising as the benefits of these expenses are not meant to be enjoyed in the immediate year but expected to have a multiplier effect over a long period of time. Capital expenditure on the short-run does usually seem like a negative decision at the time of making them but later result into positivity as the spillover effect begins to surface.

Table 3 above also indicates a high and significant relationship exist between all the variables (independent and dependent) taken together. The high level of correlation between the variables has been further supported by the results of other test statistics like the $\mathrm{R}^{2}$ and the adjusted $\mathrm{R}^{2}$ respectively. This means that $88 \%$ of the variations in GDP are explained by the variables in the model and the remaining $12 \%$ is accounted for by the stochastic variable or error term and $86 \%$ of the variations in GDP are explained by the variables while $14 \%$ is accounted for by the stochastic variable or error term in the adjusted $\mathrm{R}^{2}$.

The t-test is done to test the significance of each of the explanatory variables using the student t-distribution test. It is carried out on a two-tail test and by comparing the T-Cal and the T-tab.

The decision rule is that If $\mathrm{T}$. Cal $>\mathrm{T}$-tab, accept $\mathrm{H} 1$ and reject $\mathrm{H} 0$ and if $\mathrm{T}-\mathrm{Cal}<\mathrm{T}$-tab, accept $\mathrm{H} 0$ and reject $\mathrm{H} 1$. 
Table 4. Summary of T-statistical test for the parameters

\begin{tabular}{|c|r|r|r|r|c|}
\hline Variables & t-calculated & t-tabulated & H0 & H1 & Remark \\
\hline Intercept & 117.53 & 1.7 & Reject & Accept & Significant \\
GDD & 1.48 & 1.7 & Accept & Reject & Insignificant \\
GED & -9.26 & 1.7 & Accept & Reject & Insignificant \\
GCE & -1.96 & 1.7 & Accept & Reject & Insignificant \\
TAX & 1.02 & 1.7 & Accept & Reject & Insignificant \\
GRE & 1.84 & 1.7 & Reject & Accept & Significant \\
\hline$T(5 \%)$ & & & & & \\
\hline
\end{tabular}

Table 4 above shows the specific strength of the explanatory variables in contributing to the variations in GDP. From the $\mathrm{t}$-table, we read $\mathrm{t}(\mathrm{df}=28)$ at $5 \%$ level of significance is greater than 1.48 for government domestic debt, -9.26 for government external debt, -1.96 for government capital expenditure, for tax revenue 1.02. Also 1.84 for government recurrent expenditure is greater than the tabulated value of 1.70 . This suggest that there is no significant contribution of government domestic debt, government external debt, government capital expenditure and tax revenue to economic growth for the period examined. This result is supported by the findings of Osuka and Ogbonna, (2010); Brasoveanu and Brasoveanu, (2008); Kochelakoka, (1996).

However, there is a significant contribution of government recurrent expenditure to growth. The result is in consonance with earlier studies conducted (Khosravi and Karimi, 2010; Barro, 1999; Mishkin; 1982).

Table 5. Summary of F-Statistical test

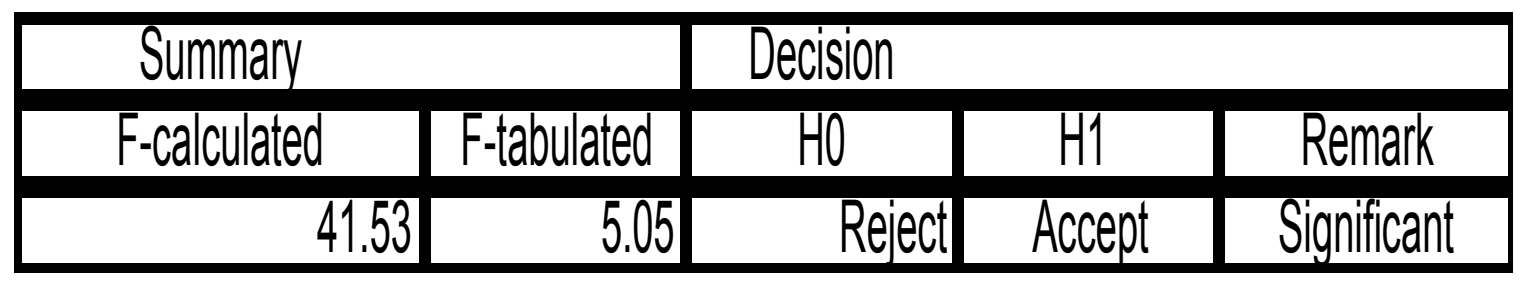

The F-test shows the statistical significance of the whole model.

Table 5 above also shows that the calculated f-ratio of 41.53 is greater than the tabulated F-ratio at $5 \%$. We reject the null hypothesis (Ho) and accept the alternative hypothesis (H1) and this concludes that a significant relationship exists between the explanatory variables (tax revenue, government domestic debt, government external debt, government recurrent expenditure, government capital expenditure) taken together and gross domestic product per capita as proxy for economic growth, for the period 1981 to 2014.

As a result of non-stationarity of data and the short run outputs of the OLS technique, spurious regression may arise. In order to tackle this challenge Augmented Dickey-Fuller (ADF) unit root test is conducted to ensure stationarity of data.

\subsection{Augmented Dickey-Fuller (ADF) Unit Root Test}

As a result of the assumption of non-stationarity of time series data results received from the OLS techniques might be unrealistic. As a consequence it is important that stationarity test is employed. The Augmented Dickey-Fuller (ADF) Unit Root Stationarity Test is conducted. This test is a critical step for the conduct of the Johnasen co-integration test. There is Stationarity if the ADF Test statistic value is greater than the Mackinnon Critical Value at $5 \%$ absolute term. Differnencing is further carried on all variables employed until the decision rule for stationarity is arrived at.

Table 6 below indicates the results of the stationarity test in summary and the order of integration. 
Table 6. ADF Unit Root Test and Order of Integration

\begin{tabular}{|ccccc|}
\hline Variables & ADF Test Statistic Value & 5\% Mackinon Critical Value & Remark & Order of Integration \\
\hline LogRPClg & -8.029593 & -2.960411 & Stationary & $\mathrm{I}(1)$ \\
LogTR & -7.279578 & -2.95711 & Stationary & $\mathrm{I}(1)$ \\
LogGED & -7.606554 & -2.960411 & Stationary & $\mathrm{I}(1)$ \\
LogGDD & -8.695958 & -2.960411 & Stationary & $\mathrm{I}(1)$ \\
LogGRE & -7.246307 & -2.95711 & Stationary & $\mathrm{I}(1)$ \\
LogGCE & -6.899329 & -2.963972 & Stationary & $\mathrm{I}(1)$ \\
\hline
\end{tabular}

Source: Authors' computation.

In Table 6, ADF statistic value is greater than the Mackinnon Critical Value @ 5\% indicating that all the variables are stationary at first difference i.e. 1(1)

Table 7. Result of Johansen Co-integration Test

\begin{tabular}{|cccc|}
\hline Maximum Eigen Value & Trace Statistics & 5\% Critical Value & Hypothesised No. \\
\hline 0.868849 & 139.2241 & 95.75366 & $r=0^{*}$ \\
0.632999 & 74.21907 & 33.87687 & $r \leq 1^{*}$ \\
0.539697 & 42.14253 & 27.58434 & $r \leq 2^{*}$ \\
0.288122 & 37.31471 & 29.79707 & $r \leq 3^{*}$ \\
0.158747 & 25.531612 & 14.26460 & $r \leq 4^{*}$ \\
\hline
\end{tabular}

Mackinnon Critical Value at 5\% levels of significance should be less than the lowest likelihood ratio to determine co-integration. The existence of cointegration determines if equilibrium correlation exist among the variables. The normalized co-integrating equation is derived from the normalized co-integrating coefficient with the lowest log likelihood.

Five co-integrating equations with a significance level at $5 \%$ employing the trace statistics are observed. It can be deduced that a long run correlation exists among the variables. The hypothesis $\mathrm{H}_{0}$ (no co-integration) is rejected. Co-integration equation derived from the Normalized co-integrating coefficients is stated below

$$
\begin{aligned}
\mathrm{RPCIg}= & 47.65614_{\mathrm{TR}}+0.187404_{\mathrm{GED}}+3.180893_{\mathrm{GDD}}-0.619957_{\mathrm{GRE}}-0.199060_{\mathrm{GCE}} \\
& (4.14273)(0.02006)(0.63691) \quad(0.13104) \quad(0.06303)
\end{aligned}
$$

Note: Values indicated in the parenthesis are standard error statistics

The independent variables TR,GED and GDD have a positive correlation with real growth rate per capita in the long run. A unit increase of TR, GED and GDD leads a corresponding increase in RPCIg by 47.65616, 0.187404 and 3.180893 units respectively from the co-integrating equation. However, the variables GRE and GCE have a negative correlation with RPCIg. Thus, an increase in either variables will lead to a decrease in RPCIg by 0.619957 and 0.1999060 units respectively in the long run.

\subsection{Vector-Auto Regression}

The vector-auto regression mechanism can now be employed as we have determined co-integration. Table 7 below depicts the vector error correction estimates: 
Table 7

Vector Error Correction Estimates

Standard errors in () \& t-statistics in [ ]

\begin{tabular}{|c|c|c|c|c|c|c|}
\hline Error Correction: & $\mathrm{D}(\mathrm{LNRGDP})$ & $\mathrm{D}(\mathrm{LNTX})$ & $\mathrm{D}($ LNGED) & $\mathrm{D}(\mathrm{LNGDD})$ & $\mathrm{D}(\mathrm{LNGRE})$ & $\mathrm{D}($ LNGCE) \\
\hline CointEq1 & $\begin{array}{r}-0.581278 \\
(0.18400) \\
{[-3.15910]}\end{array}$ & $\begin{array}{r}1.321748 \\
(0.49630) \\
{[2.66318]}\end{array}$ & $\begin{array}{r}-0.717537 \\
(1.48797) \\
{[-0.48222]}\end{array}$ & $\begin{array}{r}-0.092815 \\
(0.50816) \\
{[-0.18265]}\end{array}$ & $\begin{array}{c}0.433356 \\
(1.00235) \\
{[0.43234]}\end{array}$ & $\begin{array}{r}0.536844 \\
(0.99558) \\
{[0.53923]}\end{array}$ \\
\hline $\mathrm{D}(\mathrm{LNRGDP}(-1))$ & $\begin{array}{c}0.315616 \\
(0.19825) \\
{[1.59204]}\end{array}$ & $\begin{array}{c}-0.23865 \\
(0.53473) \\
{[-0.44630]}\end{array}$ & $\begin{array}{r}-0.944022 \\
(1.60317) \\
{[-0.58885]}\end{array}$ & $\begin{array}{r}-0.075275 \\
(0.54750) \\
{[-0.13749]}\end{array}$ & $\begin{array}{r}-0.793274 \\
(1.07996) \\
{[-0.73454]}\end{array}$ & $\begin{array}{r}1.846279 \\
(1.07266) \\
{[1.72121]}\end{array}$ \\
\hline $\mathrm{D}(\mathrm{LNRGDP}(-2))$ & $\begin{array}{c}0.179720 \\
(0.18092) \\
{[0.99339]}\end{array}$ & $\begin{array}{c}-1.74582 \\
(0.48799) \\
{[-3.57761]}\end{array}$ & $\begin{array}{r}-3.848608 \\
(1.46303) \\
{[-2.63057]}\end{array}$ & $\begin{array}{c}0.442451 \\
(0.49964) \\
{[0.88554]}\end{array}$ & $\begin{array}{r}-0.732649 \\
(0.98555) \\
{[-0.74339]}\end{array}$ & $\begin{array}{r}-2.213651 \\
(0.97890) \\
{[-2.26137]}\end{array}$ \\
\hline $\mathrm{D}(\mathrm{LNTX}(-1))$ & $\begin{array}{r}-0.177814 \\
(0.07053) \\
{[-2.52120]}\end{array}$ & $\begin{array}{c}0.376428 \\
(0.19023) \\
{[1.97878]}\end{array}$ & $\begin{array}{r}-0.551336 \\
(0.57034) \\
{[-0.96668]}\end{array}$ & $\begin{array}{r}-0.166536 \\
(0.19478) \\
{[-0.85501]}\end{array}$ & $\begin{array}{c}0.009082 \\
(0.38420) \\
{[0.02364]}\end{array}$ & $\begin{array}{r}0.367176 \\
(0.38161) \\
{[0.96219]}\end{array}$ \\
\hline $\mathrm{D}(\mathrm{LNTX}(-2))$ & $\begin{array}{r}-0.188932 \\
(0.06557) \\
{[-2.88123]}\end{array}$ & $\begin{array}{r}-0.035103 \\
(0.17687) \\
{[-0.19847]}\end{array}$ & $\begin{array}{r}-0.013618 \\
(0.53028) \\
{[-0.02568]}\end{array}$ & $\begin{array}{r}-0.059145 \\
(0.18110) \\
{[-0.32659]}\end{array}$ & $\begin{array}{r}-0.007919 \\
(0.35721) \\
{[-0.02217]}\end{array}$ & $\begin{array}{r}-0.193039 \\
(0.35480) \\
{[-0.54407]}\end{array}$ \\
\hline D(LNGED(-1)) & $\begin{array}{c}5.95 \mathrm{E}-06 \\
(0.02682) \\
{[0.00022]}\end{array}$ & $\begin{array}{r}-0.045603 \\
(0.07234) \\
{[-0.63044]}\end{array}$ & $\begin{array}{c}0.353996 \\
(0.21687) \\
{[1.63229]}\end{array}$ & $\begin{array}{c}0.027340 \\
(0.07406) \\
{[0.36914]}\end{array}$ & $\begin{array}{c}0.163281 \\
(0.14609) \\
{[1.11766]}\end{array}$ & $\begin{array}{r}-0.19468 \\
(0.14510) \\
{[-1.34165]}\end{array}$ \\
\hline $\mathrm{D}($ LNGED $(-2))$ & $\begin{array}{c}0.014614 \\
(0.02719) \\
{[0.53742]}\end{array}$ & $\begin{array}{c}-0.19772 \\
(0.07335) \\
{[-2.69560]}\end{array}$ & $\begin{array}{r}-0.207353 \\
(0.21991) \\
{[-0.94291]}\end{array}$ & $\begin{array}{c}0.038286 \\
(0.07510) \\
{[0.50980]}\end{array}$ & $\begin{array}{r}-0.138864 \\
(0.14814) \\
{[-0.93740]}\end{array}$ & $\begin{array}{r}0.057469 \\
(0.14714) \\
{[0.39058]}\end{array}$ \\
\hline $\mathrm{D}(\operatorname{LNGDD}(-1))$ & $\begin{array}{r}-0.105723 \\
(0.08282) \\
{[-1.27655]}\end{array}$ & $\begin{array}{r}-1.012931 \\
(0.22339) \\
{[-4.53441]}\end{array}$ & $\begin{array}{c}0.290766 \\
(0.66974) \\
{[0.43415]}\end{array}$ & $\begin{array}{c}0.123934 \\
(0.22872) \\
{[0.54185]}\end{array}$ & $\begin{array}{r}-0.013295 \\
(0.45116) \\
{[-0.02947]}\end{array}$ & $\begin{array}{r}-0.918155 \\
(0.44811) \\
{[-2.04893]}\end{array}$ \\
\hline $\mathrm{D}(\operatorname{LNGDD}(-2))$ & $\begin{array}{c}0.186152 \\
(0.09572) \\
{[1.94479]}\end{array}$ & $\begin{array}{c}0.606549 \\
(0.25818) \\
{[2.34933]}\end{array}$ & $\begin{array}{r}0.112630 \\
(0.77405) \\
{[0.14551]}\end{array}$ & $\begin{array}{c}0.175567 \\
(0.26435) \\
{[0.66415]}\end{array}$ & $\begin{array}{r}-0.270919 \\
(0.52143) \\
{[-0.51957]}\end{array}$ & $\begin{array}{r}0.898366 \\
(0.51791) \\
{[1.73461]}\end{array}$ \\
\hline $\mathrm{D}(\operatorname{LNGRE}(-1))$ & $\begin{array}{c}0.160191 \\
(0.05590) \\
{[2.86544]}\end{array}$ & $\begin{array}{r}-0.054441 \\
(0.15079) \\
{[-0.36104]}\end{array}$ & $\begin{array}{r}-0.290913 \\
(0.45209) \\
{[-0.64349]}\end{array}$ & $\begin{array}{c}0.101544 \\
(0.15439) \\
{[0.65770]}\end{array}$ & $\begin{array}{r}-0.540401 \\
(0.30454) \\
{[-1.77446]}\end{array}$ & $\begin{array}{r}-0.218193 \\
(0.30249) \\
{[-0.72133]}\end{array}$ \\
\hline $\mathrm{D}(\mathrm{LNGRE}(-2))$ & $\begin{array}{c}0.111035 \\
(0.06283) \\
{[1.76729]}\end{array}$ & $\begin{array}{c}0.765749 \\
(0.16946) \\
{[4.51865]}\end{array}$ & $\begin{array}{c}0.192092 \\
(0.50807) \\
{[0.37808]}\end{array}$ & $\begin{array}{c}0.078754 \\
(0.17351) \\
{[0.45388]}\end{array}$ & $\begin{array}{c}0.037830 \\
(0.34226) \\
{[0.11053]}\end{array}$ & $\begin{array}{r}-0.104344 \\
(0.33994) \\
{[-0.30694]}\end{array}$ \\
\hline $\mathrm{D}(\mathrm{LNGCE}(-1))$ & $\begin{array}{c}0.122329 \\
(0.08222) \\
{[1.48776]}\end{array}$ & $\begin{array}{r}-0.482984 \\
(0.22178) \\
{[-2.17776]}\end{array}$ & $\begin{array}{c}0.364105 \\
(0.66492) \\
{[0.54759]}\end{array}$ & $\begin{array}{c}0.213989 \\
(0.22708) \\
{[0.94236]}\end{array}$ & $\begin{array}{r}-0.045044 \\
(0.44792) \\
{[-0.10056]}\end{array}$ & $\begin{array}{r}-0.132928 \\
(0.44489) \\
{[-0.29879]}\end{array}$ \\
\hline $\mathrm{D}(\mathrm{LNGCE}(-2))$ & $\begin{array}{c}0.119136 \\
(0.06164) \\
{[1.93264]}\end{array}$ & $\begin{array}{c}0.201296 \\
(0.16627) \\
{[1.21064]}\end{array}$ & $\begin{array}{r}-0.074611 \\
(0.49850) \\
{[-0.14967]}\end{array}$ & $\begin{array}{c}0.170615 \\
(0.17024) \\
{[1.00217]}\end{array}$ & $\begin{array}{c}0.038187 \\
(0.33581) \\
{[0.11372]}\end{array}$ & $\begin{array}{r}0.400068 \\
(0.33354) \\
{[1.19945]}\end{array}$ \\
\hline C & $\begin{array}{r}-0.015142 \\
(0.03634) \\
{[-0.41668]}\end{array}$ & $\begin{array}{c}0.245890 \\
(0.09802) \\
{[2.50857]}\end{array}$ & $\begin{array}{c}0.341809 \\
(0.29388) \\
{[1.16311]}\end{array}$ & $\begin{array}{c}0.050750 \\
(0.10036) \\
{[0.50567]}\end{array}$ & $\begin{array}{r}0.427438 \\
(0.19796) \\
{[2.15916]}\end{array}$ & $\begin{array}{c}0.218593 \\
(0.19663) \\
{[1.11171]}\end{array}$ \\
\hline
\end{tabular}

This study analyzed empirically fiscal policy as a regulatory tool in enhancing economic growth through the use of fiscal policy instruments such as tax revenue, domestic debt, external debt, capital expenditure and recurrent expenditure. It employed the use of ordinary least square multiple regression analytical method and Vector Auto 
Regression (VAR) in the analyses of data for the research. It is therefore established by the study that total recurrent expenditure is an important determinant of economic growth in Nigeria. The outcome of this result is consistent with and strongly upheld the Keynesian's view that government expenditure causes economic growth. The regression results, however, reveal that the total recurrent expenditure is characterized by the higher positive value of coefficient as compared to that of the total capital expenditure, tax revenue, external debt, and domestic debt, The results also reveal that every well utilized naira unit of recurrent expenditure, capital expenditure, domestic debt, external debt and tax revenue has the ability to impact positively on economic growth of Nigeria. A good performance of an economy in terms of per capita growth may therefore be attributed to a judicious use of total government expenditure in Nigeria.

The major policy implication of this result is that concerted effort should be made by policy makers to ensure that the disbursement of government expenditure to various sectors of the economy are well supervised and also ensure its adequate spending so as to boost the level of economic growth in Nigeria. Furthermore, the implication of the study clearly shows that factors such as policy inconsistencies, high level of corruption, wasteful spending, poor policy implementation in Nigeria are capable of hampering the effectiveness of fiscal policy in achieving sustainable economic growth in the country. However, government recurrent expenditure and external debts have contributed to the growth of the nation. This means that government should ensure that public expenditures are properly managed to achieve the desired macroeconomic objectives.

\section{Conclusion}

This paper examines fiscal policy regulation as a tool in enhancing economic growth in Nigeria. The results of the OLS Test-Statistics indicates that tax revenue, external borrowings, government domestic debt and government capital expenditure have not contributed significantly to economic growth and poverty reduction in Nigeria. However, government recurrent expenditure was found to be statistically significant and impacted on the gross domestic product per capita. The results form the F-statistics analyzed suggest that a significant relationship exists between the explanatory variables (tax revenue, government domestic debt, government external debt, government recurrent expenditure, government capital expenditure) taken together and gross domestic product per capita as proxy for economic growth, for the period 1981 to 2014. The fiscal policy variables and the gross domestic product per capita were found to have a long run relationship as a result of the co-integration test. Vector auto-regression estimates; further indicates the effect of fiscal policy variables (tax revenue, government domestic debt, government external debt, government recurrent expenditure, government capital expenditure) employed in the study on economic growth and the existence of long run equilibrium between the endogenous and exogenous variables. The study suggests that total recurrent expenditure is a vital fiscal policy tool in enhancing economic growth in Nigeria. The outcome of this result lends credence with and strongly supports the Keynesian's hypothesis that government expenditure causes economic growth. A good performance of an economy in terms of per capita growth may therefore be attributed to a judicious use of total government expenditure in Nigeria. The major policy implication of this result is that concerted effort should be made by policy formulators to ensure that the disbursement of government expenditure to various sectors of the economy are well monitored and also ensure its adequate spending so as to enhance economic growth in Nigeria.

\section{References}

Adefeso, H. A., \& Mobalaji, H. I. (2010). The fiscal-monetary policy and economic growth in Nigeria: Further empirical evidence. Journal of Social Sciences, 7(2), 137-142.

Adeoye, T. (2006). Fiscal policy and growth of the Nigerian economy: An empirical perspective (NISER Monograph Series, P10). Ibadan, Nigeria: Nigerian Institute of Social and Economic Research.

Afonso, A., \& Sousa, R. M. (2012). The macroeconomic effects of fiscal policy. Applied Economics, 44(34), 4439-4454.

Amin, A. A. (1999). An examination of the sources of economic growth in Cameroon's economy (AERC revised final report). Nairobi, Kenya: African Economic Research Consortium

Arestis, P. (2009). New consensus macroeconomics: A critical appraisal, The Levy Economics Institute of Bard College working paper, 564.

Asaju,K. Adagba,S.O \& Kajang,T.J (2014). The Efficacy of Fiscal Policy in Promoting Economic Growth and Reducing Poverty in Nigeria. Research in World Economy 5(1)

Auerbach, A. J. (2009). Implementing the new fiscal policy activism (NBER Working Paper No. 14725). Cambridge, MA: National Bureau of Economic Research. 
Auerbach, A. J. (2012). The fall and rise of Keynesian fiscal policy, Asian Economic Policy Review, 7(2), 157-175. Retrieved

from http://onlinelibrary.wiley.com.ezproxy.brunel.ac.uk/doi/10.1111/j.17483131.2012.01228.x/full

Auerbach, A. J., \& Gorodnichenko, Y. (2012). Measuring the output responses to fiscal policy, American Economic Journal: Economic Policy, 4(2), 1-27. http://dx.doi.org/10.1257/pol.4.2.1

Barro, R. (1999). Notes on Growth Accounting. Journal of Economic Growth, 4, 119-137. http://dx.doi.org/10.1023/A:1009828704275

Baunsgaard, T (2003). Fiscal Policy in Nigeria: Any Role for Rules? International Monetary Fund Working Paper Number WP/ 03/155.

Beetsma, R. (2008). A survey of the effects of discretionary fiscal policy, Swedish Fiscal Policy Council, 2.

Beetsma, R., \& Giuliodori, M. (2011). The effect of government purchases shocks: Review and estimates for the EU. The Economic Journal, 121, 4-32. http://dx.doi.org/10.1111/j.1468-0297.2010.02413.x

Bertola, G., \& Drazen, A. (1993). Trigger points and budget cuts: Explaining the effects of fiscal austerity.American Economic Review, 83, 11-26. Retrieved from http://www.jstor.org.ezproxy.brunel.ac.uk/stable/2117493

Brasoveanu, L. O., \& Brasoveanu, I. (2008). The Correlation between Fiscal Policy and Economic Growth. Journal of Theoretical and Applied Economics, 20-26.

Chuku, A. C. (2010). Monetary and fiscal policy interactions in Nigeria: An application of a state-space model with Markov switching. Journal of Applied Statistics, 1, 39-51

Fontana, G. (2009). The transmission mechanism of fiscal policy: a critical assessment of current theories and empirical methodologies, Journal of Post Keynesian Economics, 31(4), 587-604. https://doi.org/10.2753\%2FPKE0160-3477310404

Galí, J., López-Salido, J. D., and Vallés, J. (2007). Understanding the effects of government spending on consumption. Journal of the European Economic Association, 5, 227-270. Retrieved from http://www.jstor.org.ezproxy.brunel.ac.uk/stable/40005166

Gemmell, N. (2011). Can a fiscal stimulus boost economic growth rates? Introduction. Economic Journal, 121:F1-F3. http://dx.doi.org/10.1111/j.1468-0297.2010.02412.x

Huang, H., \& Padilla, A. J. (2002). Fiscal policy and the implementation of the Walsh Contract for Central Banker's. Annals of Economics and Finance, 3, 27-42.

Ingen,C.V, Wait,R. and Kleynhans,E. (2014). Fiscal policy and revenue management in resource-rich African countries: A comparative study of Norway and Nigeria, South African Journal of International Affairs, 21(3), 367-390. http://dx.doi.org.ezproxy.brunel.ac.uk/10.1080/10220461.2014.968200

Khosravi, A., \& Karimi, M. S. (2010). To Investigate the Relationship between Monetary Policy, Fiscal Policy and Economic Growth in Iran: Autoregressive Distributed Lag Approach to Cointegration. American Journal of Applied Sciences, 7(3), 420-424.

Kwakwa, V. (2003). A Framework for Assessing Fiscal Sustainability: Application to Nigeria. Third Annual Monetary Policy Conference Proceedings on Issues in Fiscal Management: Implications for Monetary Policy in Nigeria, 11-12 December 2003 (Lagos, Central Bank of Nigeria Publication).

Mishkin, F. S. (1982). Does anticipate Monetary Policy Matter: An Economic Investigation. Journal of Political Economics, 90, 22-51.

Njoku, A., \& Ihugba, O. A. (2011). Unemployment and Nigerian economic growth (1985-2009). In Proceedings of the International Conference on Teaching, Learning and Change (Organized by International Association for Teaching and Learning [IATEL]).

Nwankwo, A. (2010, November 17). Nigeria's foreign debt: The good, bad and bizzare. Vanguard newspaper. Retrieved from http://www. vanguardngr.com/2010/11/nigerias foreign-debt he-good-badand-bizzare/

Ogbole, F. O., Amadi, S. N., \& Essi, I. D. (2011). Fiscal policy: Its impact on economic growth in Nigeria (1970-2006). Journal of Economics and International Finance, 3, 407-417.

Okwo, I. M. (2010). An overview of public debt and its management strategies in Nigeria (1980-2007). ESUT Journal of Accountancy, 1, 237-248. 
Olajide, B., \& Adekoya, F. (2012). Economic healing: Revisiting 2012 fiscal policy. Retrived from http://www.nigerianbestforum.com

Olawunmi, O., \& Ayinla, T. A. (2007). Fiscal policy and Nigerian economic growth. Journal of Research in National Development, 5(2), 19-29.

Omitogun, O., \& Ayinla, T. A. (2007). Fiscal policy and Nigeria economic retirement. Retrieved from http://www.termpaperwarehouse.com

Osuka, B. O and Ogbonna, B. C. (2010). The Impact of Fiscal Policy on Economic Development in Nigeria. Journal of Public Policy Analysis, 3(1)

Perotti, R. (2007). In search of the transmission mechanism of fiscal policy, NBER working paper, 13143.

Ravn, M., Schmitt-Grohé, S., and Uribe, M. (2006). Deep Habits. Review of Economic Studies, 73, 195-218. Retrieved from http://www.jstor.org.ezproxy.brunel.ac.uk/stable/3700622

Salami, A. (2011). Taxation, Revenue Allocation and Fiscal Federalism in Nigeria: Issues, Challenges and Policy Options. Ekonomski anali, LVI(189). http://dx.doi.org/10.2298/EKA1189027S

Sunderland, A. (1997). Fiscal crises and aggregate demand: Can high public debt reverse the effects of fiscal $\begin{array}{lllll}\text { policy? Journal of Public } & \text { Economics, } & 65, & \text { 147-162. }\end{array}$ http://dx.doi.org.ezproxy.brunel.ac.uk/10.1016/S0047-2727(97)00027-3

\section{Copyrights}

Copyright for this article is retained by the author(s), with first publication rights granted to the journal.

This is an open-access article distributed under the terms and conditions of the Creative Commons Attribution license (http://creativecommons.org/licenses/by/4.0/). 